\title{
Aggregation of euphausiids along a coastal shelf in an upwelling environment
}

\author{
Yvan Simard*, Réjean de Ladurantaye \& Jean-Claude Therriault \\ Centre Champlain des Sciences de la mer, Ministère des Pêches et des Océans, C.P. 15500, 901 Cap Diamant, Québec, Québec \\ GIK 7Y7, Canada
}

\begin{abstract}
Spatial distribution of biomass of euphausiids in the St. Lawrence estuary was investigated using high frequency $(104 \mathrm{kHz})$ echo integration. Most of the euphausiids were aggregated in a long $(>100 \mathrm{~km})$ narrow $(1$ to $7 \mathrm{~km}$ ) patch along the northern edge of the Laurentian Channel. Biomass in the patch was higher than $1 \mathrm{~g}$ dry wt $\mathrm{m}^{-2}$ and showed well-defined zones of a few $\mathrm{km}^{2}$ with higher biomasses (up to $22.2 \mathrm{~g}$ dry $\mathrm{wt}^{-2}$ ). Mean density in the patch was $\sim 60 \mathrm{mg} \mathrm{dry}$ wt $\mathrm{m}^{-3}$. Euphausids were found at depths varying between 50 and $175 \mathrm{~m}$, often with large concentrations just above the bottom. The vertical distribution was characterized by 2 principal modes, at 75 and $150 \mathrm{~m}$. In the first mode. Thysanoessa raschi was the dominant organism while in the second mode, Meganyctiphanes norvegica was dominant. Vertical and horizontal distribution patterns of temperature and salinity indicated that upwelling was occurring during the survey. It is suggested that the aggregation of euphausiids along one edge of the channel resulted from the interaction of the negative phototaxis of the animals with the upwelling and mean circulation in the area. The euphausiids were passively transported towards the north shore by the circulation, up to a boundary corresponding to a barrier imposed by underwater daylight penetration, where they accumulated. This resulted in the formation of a long narrow patch along bathymetric contours on the upwelling side of the Laurentian Channel in the St. Lawrence estuary.
\end{abstract}

\section{INTRODUCTION}

It has long been known that zooplankton is not evenly or randomly distributed in the sea, but rather aggregated in patches varying in size over a wide range of scales (see review by Haury et al. 1978). These aggregations are controlled by various environmental and biological processes acting on different time and space scales (Haury et al. 1978, Longhurst 1981, Owen 1981, Mackas et al. 1985). Since aggregation of food is necessary for efficient feeding at all trophic levels, identification of aggregation mechanisms is of major importance for our understanding of energy flow in the marine food web, as well as of factors regulating the stability of marine ecosystems (Steele 1976, 1978).

The study of spatial organization of zooplankton at sea requires well-defined sampling strategies and adequate instruments to control the high level of variability inherent to plankton distribution (Denman \& Mackas 1978, Haury et al. 1978, Herman \& Platt 1980,

\footnotetext{
- Present address: Institute of Ocean Sciences, P.O. Box 6000 , Sidney, British Columbia V8L 4B2, Canada
}

Ortner et al. 1983). One of the methods recently developed to study the spatial distribution of macrozooplankton is the use of high frequency echosounding to locate aggregations and estimate their biomass. Pieper (1979) and Sameoto (1980) have shown that this technique gives good estimates of euphausiid biomass. It has the main advantages of estimating zooplankton concentrations easily and rapidly in large volumes, and continuously in 2 dimensions (Denman \& Mackas 1978, Pieper 1983). In this paper we use such a technique to study the distribution of euphausiids in the Lower St. Lawrence estuary. Our aim was (1) to estimate euphausiid biomass in the scattering layers, (2) to study distribution and aggregation in both horizontal and vertical dimensions, and (3) to investigate the mechanisms responsible for patch formation and maintenance. In agreement with Mauchline (1980), we use the term 'aggregation' as designating a grouping together of the animals; it does not, however, qualify the structure or the mechanism of formation. A 'patch' is an aggregation in a defined area, generated and maintained by environmental factors. An accumulation' is an aggregation where the animals are gradu- 
ally concentrated in response to mechanisms other than behavioral reactions between individuals.

\section{METHODS}

The sampling area was the upstream $110 \mathrm{~km}$ of the lower St. Lawrence estuary (Fig. 1). The bathymetry in this area is characterized by the presence of a $300 \mathrm{~m}$ deep depression, the Laurentian Channel, which communicates directly with the Gulf of St. Lawrence and the Atlantic ocean. This channel is bordered on both sites by coastal shelves $<100 \mathrm{~m}$ deep, except in the region upstream of Les Escoumins where the north coast falls directly into the channel. Sampling was done along 5 transects between 22 and 26 July 1982, during the transition period from spring $(4.5 \mathrm{~m})$ to neap $(3 \mathrm{~m})$ tides. The positioning of transects (Fig. 1) gave emphasis to measurements along the channel slopes, where a preliminary survey in May 1982 had shown higher zooplankton concentrations.

The scattering layers were continuously monitored with a Ross-805 echosounder, equipped with a $104 \mathrm{kHz}$ transducer of $3.5^{\circ}$ half-power beam width mounted into a towed fish. Towing speed was about 5 knots. Acoustic signals were digitized on board with a 12 bit analog/digital interface connected to an Apple II micro-computer, and the average of 112 signals ( $1 \mathrm{~min}$ ) was recorded at $2 \mathrm{~min}$ intervals. All transect measurements started on the north shore and were carried out during daytime (from $0730 \mathrm{~h}$ EDT to $1830 \mathrm{~h}$ EDT), when the vertically migrating zooplankton was at its day depth. The recorded acoustic data series were regularly interrupted for CTD profiling (CTD Guildline-8750) and zooplankton sampling in the scattering layers. Additional CTD profiles were also made along the transects during the night, on the way back to the north shore. The positions of the 87 CTD profiles made during the survey are indicated in Fig. 1. The zooplankton samples were collected using a modified opening/closing Tucker Trawl (Sameoto \& Jarozynski 1976) with a $1 \mathrm{~m}^{2}$ mouth opening, a $570 \mu \mathrm{m}$ mesh blue net and a flowmeter. Fishing depth was monitored with a Sea-Trace (Communications Associates Inc., Huntington, New York) acoustic depth monitoring system (a pressure sensitive transducer linked to a deck unit through a surface hydrophone). Towing speed was - 3 to 4 knots, and the volume of water filtered averaged $300 \mathrm{~m}^{3}$ (range: 180 to $460 \mathrm{~m}^{3}$ ). The zooplankton samples were frozen $\left(-20^{\circ} \mathrm{C}\right)$ for later analysis in the laboratory. A total of 29 tows were made (Fig. 1).

Euphausids in the zooplankton samples were sorted, identified, counted and weighed (dry weight). The acoustic data were used to compute the relative zooplankton biomass $\mathrm{m}^{-3}$ within the water column $(\rho)$ according to the standard echo integration model (Burczynski 1979):

$$
\mathrm{I}_{\mathrm{e}} \propto \mathrm{I}_{\mathrm{o}} \cdot \mathrm{r}^{-2} \cdot 10^{-2 \alpha r} \cdot \rho \bar{\sigma}
$$

where $\mathrm{I}_{\mathrm{e}}=$ echo intensity; $\mathrm{I}_{\mathrm{o}}=$ source intensity; $\mathrm{r}=$ range from the transducer (depth) $\alpha=$ absorption coefficient of sound; $\rho=$ relative zooplankton biomass $\mathrm{m}^{-3} ; \bar{\sigma}=$ mean equivalent backscattering cross-sec-

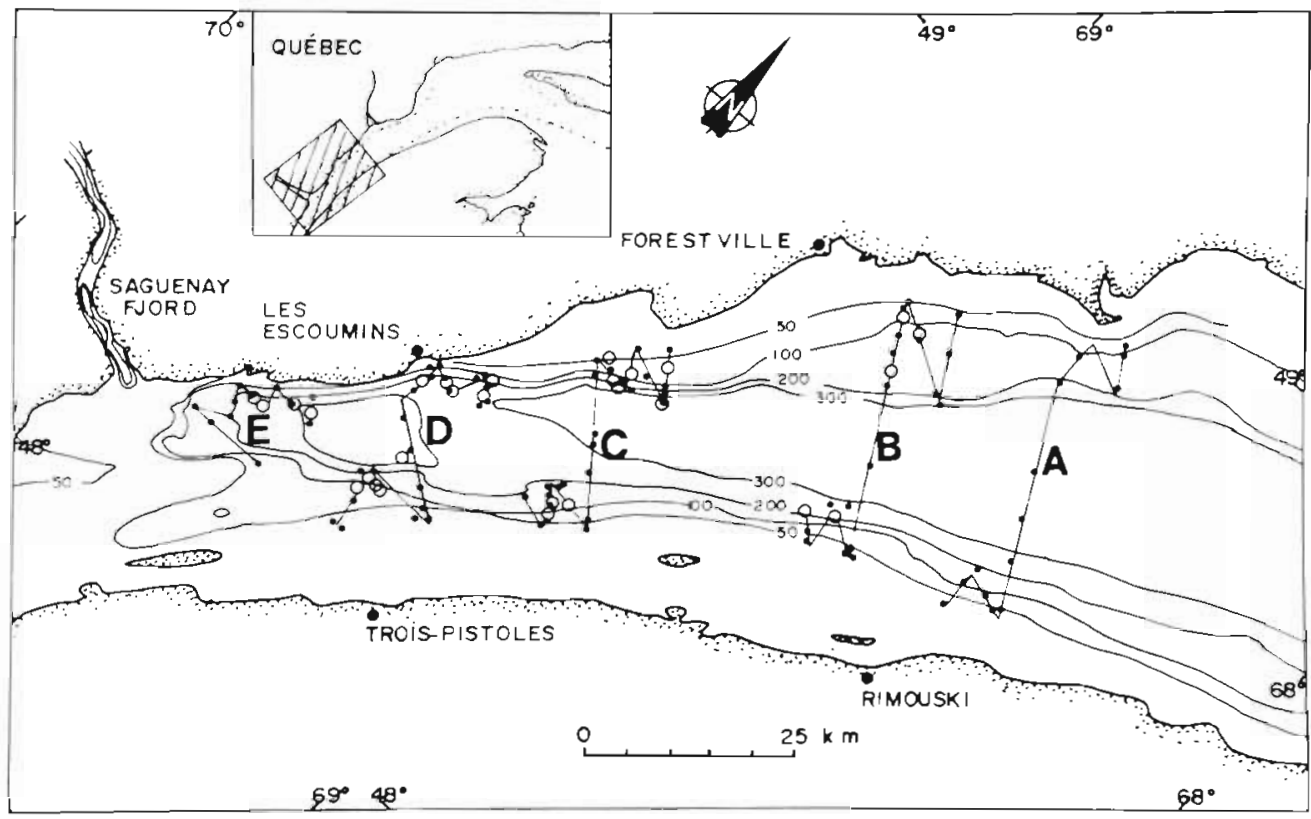

Fig. 1. Map of study area showing isobath contours $(\mathrm{m})$, positions of the 5 echosounding transects and positions of CTD profiles $(\cdot)$ and net tows (o) 
tion of a zooplankter. Since $I_{e} \propto V^{2}$, for $I_{0}$ and $\bar{\sigma}$ constant, we get:

$$
\rho \propto V^{2} r^{2} 10^{2 \alpha T}
$$

where $\mathrm{V}=$ recorded raw voltage corrected for system noise.

According to this model, the relative zooplankton biomass $\mathrm{m}^{-3}(\rho)$ is proportional to the squared voltage $\left(\mathrm{V}^{2}\right)$ corrected for the decrease in sound intensity due to spreading $\left(\mathrm{r}^{4}\right)$ and attenuation $\left(10^{2 \mathrm{~m}}\right)$ and for the insonified volume $\left(\mathrm{r}^{-2}\right)$. This relative zooplankton biomass could then be transformed in an absolute estimate ( $\mathrm{mg}$ dry weight $\mathrm{m}^{-3}$ ) by mean of a linear regression on euphausiid biomass from net tows (Fig. 2). The biomass of euphausiids $\mathrm{m}^{-2}$ was obtained by integrating over depth, from $30 \mathrm{~m}$ to the bottom.

\section{RESULTS}

The horizontal distribution of the biomass of euphausiids in the study area shows that they were mainly concentrated in a long narrow patch along the northern side of the Laurentian Channel (Fig. 3). Its length extended beyond the $100 \mathrm{~km}$ surveyed and its width varied between 1 and $7 \mathrm{~km}$. The biomass within the patch was higher than $1 \mathrm{~g}$ dry wt $\mathrm{m}^{-2}$ and showed well-defined zones of higher values at various locations, up to $\sim 22.2 \mathrm{~g}$ dry $\mathrm{wt} \mathrm{m}^{-2}$. The densest zones (>15 $\mathrm{g}_{\text {dry }}$ wt $\mathrm{m}^{-2}$ ) were located off Les Escoumins and in the downstream section of the sampling area. The biomass outside of this elongated northern patch was distributed in very small patches of values higher than $1 \mathrm{~g}$ dry wt $\mathrm{m}^{-2}$, which were enveloped in a narrow low-biomass $\left(0.25\right.$ to $1 \mathrm{~g}$ dry $\left.\mathrm{wt}^{-2}\right)$ area along the

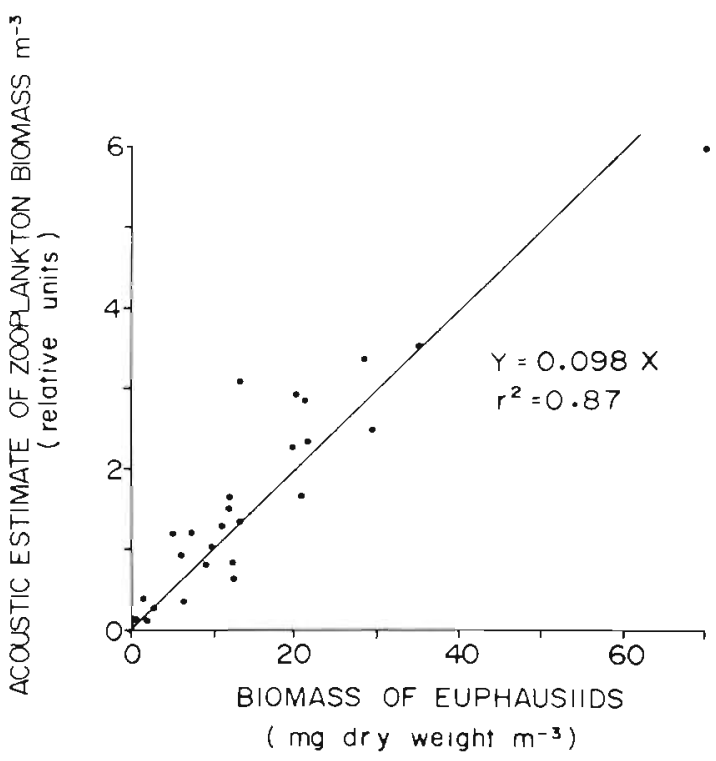

Fig. 2. Relation between the acoustic estimates of zooplankton biomass ( $\rho$ ) and euphausiid biomass (dry weight) from net catches. Regression equation and Pearson $r^{2}$ when forced through the origin

southern side of the channel. In the middle of the channel, the background biomass gradually decreased from $0.5 \mathrm{~g}$ dry $w t \mathrm{~m}^{-2}$ in the upstream region to negligible values $<0.25 \mathrm{~g}$ dry $\mathrm{wt}^{-2}$ downstream. No significant biomass was recorded in areas shallower than $40 \mathrm{~m}$ on both sides of the Laurentian Channel. In brief, the overall distribution of euphausiid biomass in the study area was U-shaped along the edges of the Laurentian Channel, with the northern branch of the $U$ much denser than the southern branch and an upstream enlargement of the base of the $\mathrm{U}$ at the head of the channel.

Fig. 3. Horizontal distribution of euphausiid biomass from acoustic estimation. Biomass contours are: 0.25, 0.5, 1 (light stippling), 2 (heavy stippling) and $>4$ (black) g dry weight $\mathrm{m}^{-2}$

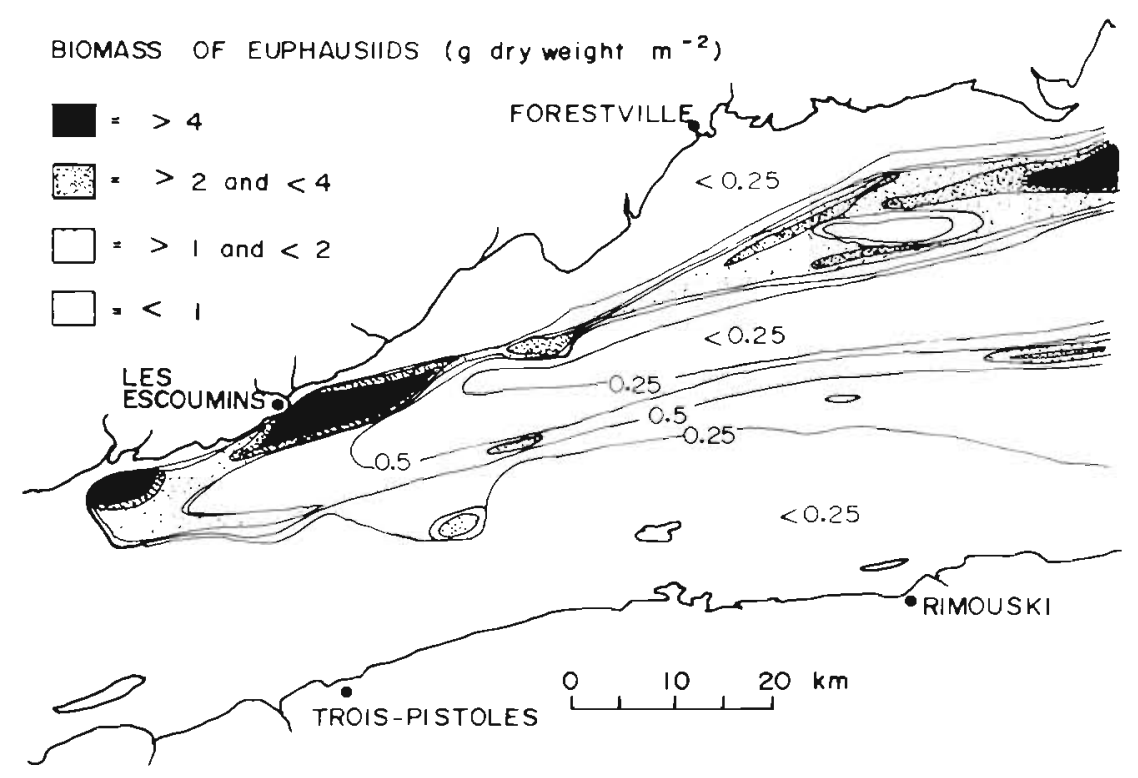


Typical representations of the vertical and horizontal structure of the aggregation along the transects are shown in Fig. 4. Most of the euphausids were found between 50 and $175 \mathrm{~m}$ and, usually, they were horizontally and vertically distributed in more than one scattering layer. The largest and densest scattering layer was located off Les Escoumins (Fig. 4: D-1). On the north shelf, significant biomasses were found close to the bottom in areas shallower than $200 \mathrm{~m}$ (e.g. Fig. 4: A-1, B-1, B-2, D-1). The maximum upper level of the scattering layers during the day was 40 to $50 \mathrm{~m}$ (e.g. Fig. 5A,B \& 6), which restricted the euphausiids to areas deeper than $40 \mathrm{~m}$ on both sides of the channel (e.g. Fig. 4: C-4, Fig. 5A, B). The euphausiid scattering layers exhibited typical diel vertical migrations. The ascent to the surface began at the end of the afternoon,
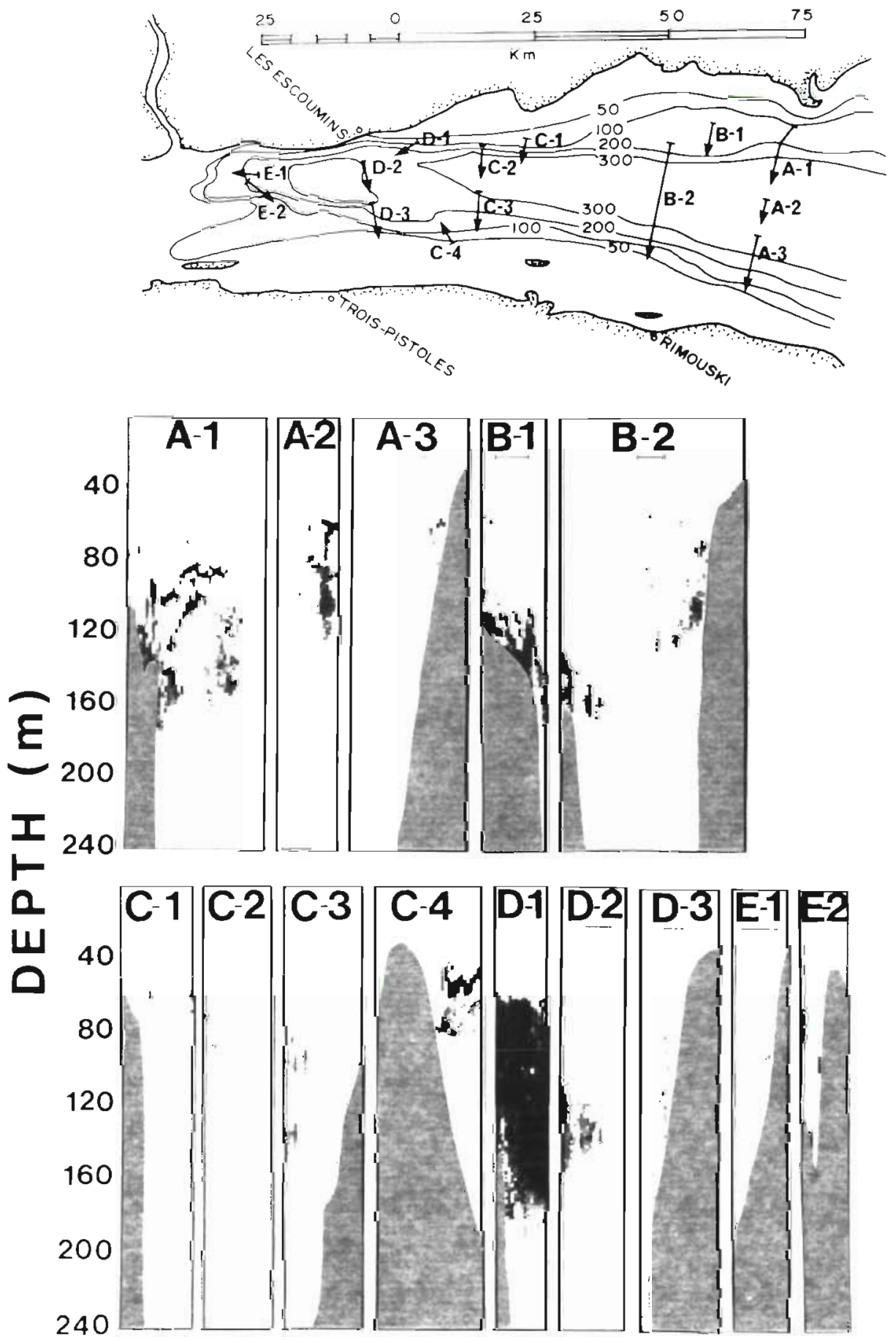

Fig. 4. Computer visualization of vertical distribution of euphausiids along transects from acoustic estimates. Increasing biomass from white to black (0 to $>13 \mathrm{mg}$ dry weight $\mathrm{m}^{-3}$ ). Bars below letters $A-1$ to $E-2$ represent $3 \mathrm{~km}$ 
Fig. 5. Echograms $(104 \mathrm{kHz})$ presenting $(A, B)$ upper level of the scattering layers during the day (A: $0800 \mathrm{~h}, \mathrm{~B}: 1130 \mathrm{~h}$ ), disappearance of the scattering layer towards the coast in areas shallower than $40 \mathrm{~cm}$, and high concentration of euphausids near the bottom; and (C) the negative phototaxis of the scattering layer during diel vertical migrations, $1 \mathrm{~h}$ before sunrise $(0520 \mathrm{~h}$ EDT) The presence of a school of bottom fishes along the slope is revealed in $B$ by a clump of discrete scatterers. Echograms are raw voltage i.e. not vertically compensated for spreading and absorption losses
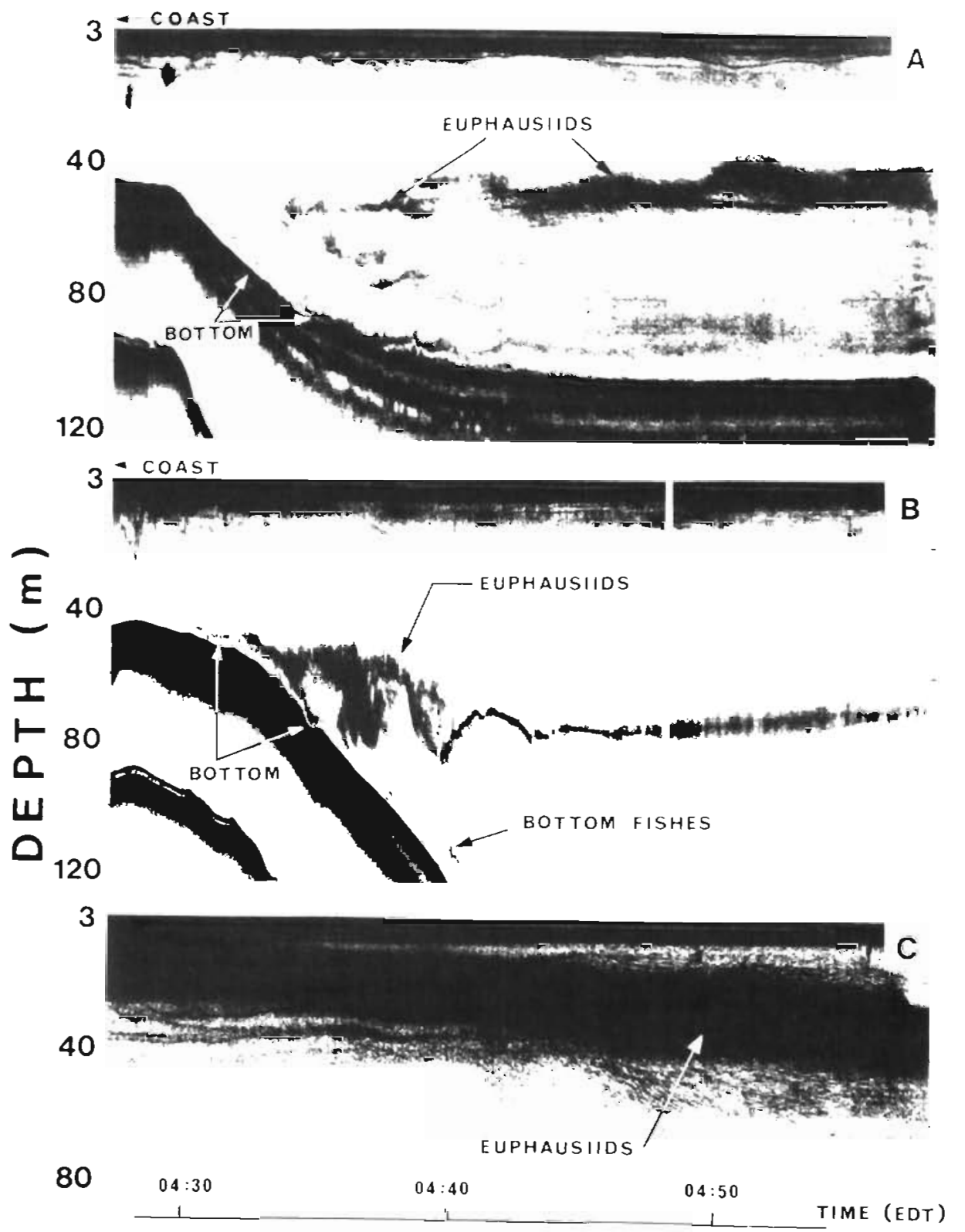

120

the surfacing occurred at sunset (2050 $\mathrm{h} \mathrm{EDT)} \mathrm{and} \mathrm{the}$ descent (Fig. 5C) began about $1 \mathrm{~h}$ before sunrise (0520 h EDT), with the first light of dawn.

For further analysis of the acoustic data, the study area was divided into 3 sections: the north, south and central sections of the transects (Fig. 1), which corresponded, respectively, to the 2 zig-zag parts and the central area of the channel. Statistics of the biomass distribution in these sections are presented in Tables 1 and 2 for each transect. The proportion of the water column inhabited by the euphausiids was generally low, except in the northern section of Transects $A$ and
D, where almost half of the water column had significant backscattering (Table 1). This is partly responsible for the spatial variations in the estimated mean density (dry biomass $\mathrm{m}^{-3}$ ) over the whole water column (Table 1). For all the transects, the mean density in the scattering layers (defined as all the biomasses $>0.5 \mathrm{mg}$ dry $\mathrm{wt} \mathrm{m}^{-3}$ ) was consistently 3 to 4 times higher in the northern section than in the central or southern sections (Table 2). The distribution of the frequency of occurrence of densities in the scattering layers indicated that most of the volume of the aggregation was everywhere due to densities $<50 \mathrm{mg}$ dry wt 


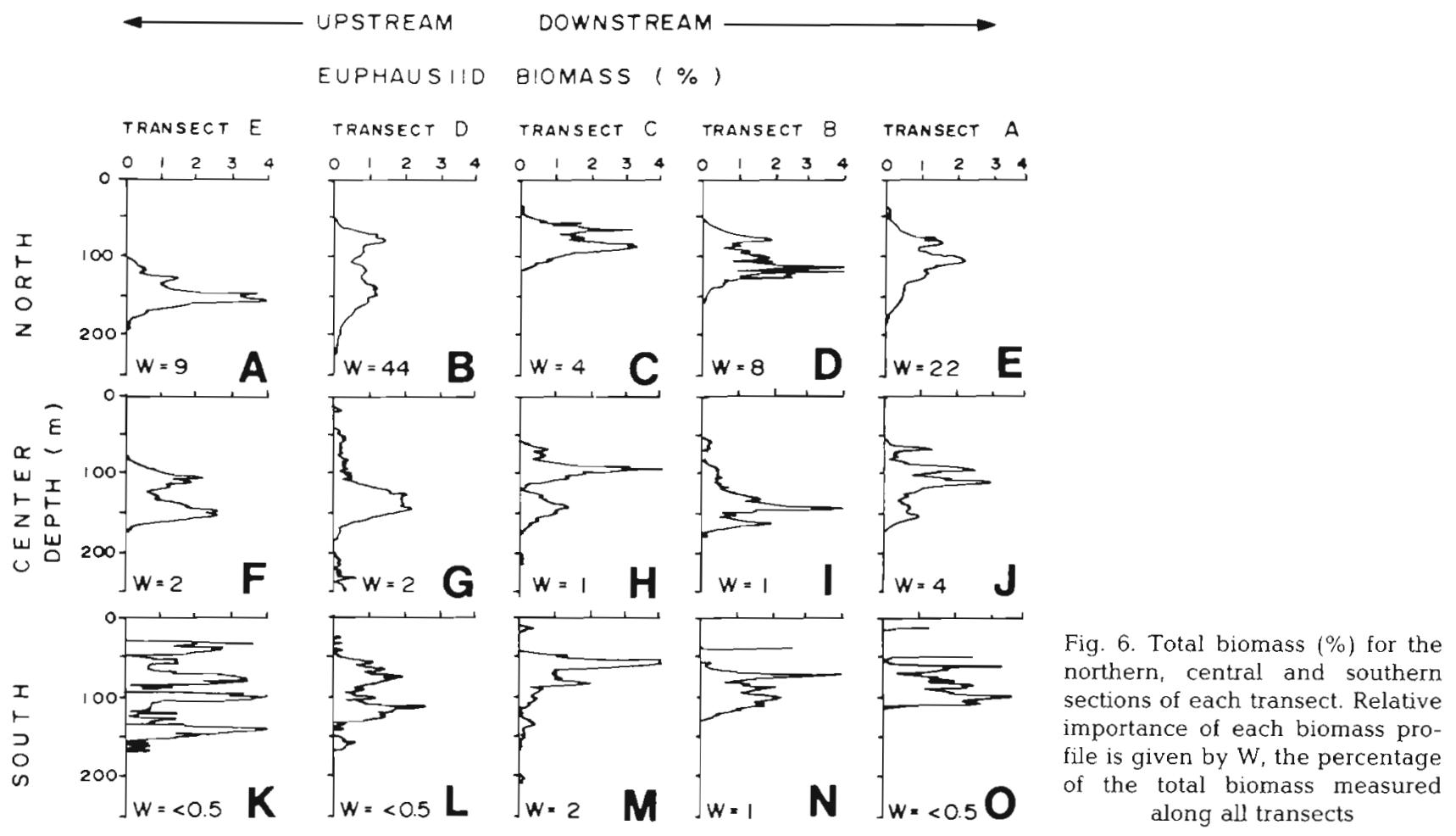

Table 1. Mean dry biomass of euphausiids ( $\mathrm{mg}$ dry wt $\mathrm{m}^{-3}$ ) in the water column estimated from acoustic data, and proportion of water column occupied by scattering layers for the northern, central and southern section of each transect

\begin{tabular}{|c|c|c|c|c|c|}
\hline Section & $\begin{array}{c}\text { Upstream } \\
\text { Transect E }\end{array}$ & Transect D & Transect C & Transect B & $\begin{array}{l}\text { ownstream } \\
\text { Transect A }\end{array}$ \\
\hline \multicolumn{6}{|l|}{ North } \\
\hline Mean dry biomass $\left(\mathrm{mg} \mathrm{m}^{-3}\right)$ & 16 & 32 & 9 & 7 & 27 \\
\hline$\%$ water column inhabited & 26 & 48 & 16 & 14 & 45 \\
\hline No. of estimates & 5056 & 12351 & 3882 & 10011 & 7276 \\
\hline \multicolumn{6}{|l|}{ Center } \\
\hline Mean dry biomass ( $\mathrm{mg} \mathrm{m}^{-3}$ ) & 4 & 2 & 1 & 1 & 2 \\
\hline$\%$ water column inhabited & 22 & 17 & 6 & 5 & 12 \\
\hline No. of estimates & 4130 & 6380 & 13965 & 9700 & 16150 \\
\hline \multicolumn{6}{|l|}{ South } \\
\hline Mean dry biomass $\left(\mathrm{mg} \mathrm{m}^{-3}\right)$ & 1 & 1 & 2 & 2 & 1 \\
\hline$\%$ water column inhabited & 3 & 8 & 9 & 12 & 5 \\
\hline No. of estimates & 4160 & 4170 & 7787 & 3749 & 6245 \\
\hline
\end{tabular}

$\mathrm{m}^{-3}$. These low densities accounted for the major part of the total biomass in the central and southern sections, but to a minor part in the north (Table 2). There, a significant portion of the biomass was due to the small parts of the scattering layers with high densities $(>200$ $\mathrm{mg}$ dry $\mathrm{wt}^{-3}$ ). Maximum density recorded was $2.5 \mathrm{~g}$ dry wt $\mathrm{m}^{-3}$.

The vertical distribution of the estimated biomass is shown in Fig. 6 for each section of the transects. The most important biomass profile (Fig. 6B) indicated that the euphausiids in the dense patch off Les Escoumins were distributed in 2 main modes: the first at $75 \mathrm{~m}$ and the second at $150 \mathrm{~m}$. One or both of these 2 modes were present in other areas (e.g. Fig. 6A, C, E, G). An additional third mode around $100 \mathrm{~m}$ also occurred occasionally (e.g. Fig. 6E, F, J). The vertical distribution of the total biomass compiled from all net catches in the study area (Fig. 7A, B) indicates that the first mode, at $75 \mathrm{~m}$, was most probably dominated by Thysanoessa raschi and the second mode, at $150 \mathrm{~m}$, by Meganyctiphanes norvegica. The modes at intermediate depths could correspond to a mixture of the 2 
Table 2. Mean and probability distribution of euphausiids density $\left(B\right.$, in $\left.m g d r y w t ~ m^{-3}\right)$ in the scattering layers for the northern, central and southern sections of each transect. Frequency of occurrence (\%) and proportion (\%) of total biomass for 4 classes of density

\begin{tabular}{|c|c|c|c|c|c|c|c|c|c|c|}
\hline \multirow[t]{3}{*}{ Section } & \multicolumn{4}{|c|}{ Upstream } & & & & & \multicolumn{2}{|c|}{ Downstream } \\
\hline & \multicolumn{2}{|c|}{ Transect E } & \multicolumn{2}{|c|}{ Transect D } & \multicolumn{2}{|c|}{ Transect $\mathrm{C}$} & \multicolumn{2}{|c|}{ Transect B } & \multicolumn{2}{|c|}{ Transect A } \\
\hline & $\begin{array}{c}\text { Occur- } \\
\text { rence } \\
(\%)\end{array}$ & $\begin{array}{c}\text { Bio- } \\
\text { mass } \\
(\%)\end{array}$ & $\begin{array}{l}\text { Occur- } \\
\text { rence } \\
(\%)\end{array}$ & $\begin{array}{c}\text { Bio- } \\
\text { mass } \\
(\%)\end{array}$ & $\begin{array}{c}\text { Occur- } \\
\text { rence } \\
(\%)\end{array}$ & $\begin{array}{c}\text { Bio- } \\
\text { mass } \\
(\%)\end{array}$ & $\begin{array}{l}\text { Occur- } \\
\text { rence } \\
(\%)\end{array}$ & $\begin{array}{l}\text { Bio- } \\
\text { mass } \\
(\%)\end{array}$ & $\begin{array}{c}\text { Occur- } \\
\text { rence } \\
(\%)\end{array}$ & $\begin{array}{c}\text { Bio- } \\
\text { mass } \\
(\%)\end{array}$ \\
\hline \multicolumn{11}{|l|}{ North } \\
\hline $0.5 \leqslant B \leqslant 50$ & 75 & 18 & 53 & 10 & 64 & 17 & 76 & 20 & 67 & 15 \\
\hline $50<B \leqslant 100$ & 13 & 16 & 27 & 30 & 19 & 27 & 13 & 22 & 16 & 20 \\
\hline $100<B \leqslant 200$ & 6 & 14 & 15 & 32 & 13 & 34 & 7 & 21 & 10 & 24 \\
\hline$B>200$ & 6 & 52 & 5 & 28 & 4 & 22 & 4 & 37 & 7 & 41 \\
\hline Mean dry biomass $\left(\mathrm{mg} \mathrm{m}^{-3}\right.$ ) & \multicolumn{2}{|c|}{59} & \multicolumn{2}{|c|}{66} & \multicolumn{2}{|c|}{55} & \multicolumn{2}{|c|}{46} & \multicolumn{2}{|c|}{60} \\
\hline No. of estimates & \multicolumn{2}{|c|}{1326} & \multicolumn{2}{|c|}{5892} & \multicolumn{2}{|c|}{606} & \multicolumn{2}{|c|}{1543} & \multicolumn{2}{|c|}{4277} \\
\hline \multicolumn{11}{|l|}{ Center } \\
\hline $0.5 \leqslant B \leqslant 50$ & 93 & 74 & 99 & 97 & 98 & 80 & 97 & 66 & 93 & 65 \\
\hline $50<B \leqslant 100$ & 6 & 22 & 1 & 3 & 1 & 5 & 1 & 9 & 5 & 17 \\
\hline $100<B \leqslant 200$ & 1 & 4 & & & 1 & 8 & 1 & 3 & 2 & 11 \\
\hline$B>200$ & & & & & $<0.5$ & 7 & 1 & 22 & $<0.5$ & 7 \\
\hline Mean dry biomass $\left(\mathrm{mg} \mathrm{m}^{-3}\right)$ & \multicolumn{2}{|c|}{19} & \multicolumn{2}{|c|}{13} & \multicolumn{2}{|c|}{15} & \multicolumn{2}{|c|}{15} & \multicolumn{2}{|c|}{20} \\
\hline No. of estimates & \multicolumn{2}{|c|}{916} & \multicolumn{2}{|c|}{1090} & \multicolumn{2}{|c|}{882} & \multicolumn{2}{|c|}{515} & \multicolumn{2}{|c|}{1971} \\
\hline \multicolumn{11}{|l|}{ South } \\
\hline $0.5 \leqslant B \leqslant 50$ & 99 & 96 & 100 & 100 & 93 & 58 & 98 & 86 & 100 & 100 \\
\hline $50<B \leqslant 100$ & 1 & 4 & & & 3 & 13 & 1 & 3 & & \\
\hline $100<B \leqslant 200$ & & & & & 3 & 21 & 1 & 11 & & \\
\hline $\mathrm{B}>200$ & & & & & 1 & 8 & & & & \\
\hline Mean dry biomass $\left(\mathrm{mg} \mathrm{m}^{-3}\right.$ ) & \multicolumn{2}{|c|}{14} & & & & & & & & 1 \\
\hline No. of estimates & & & & & & & & & & \\
\hline
\end{tabular}

species. The euphausiids caught were adults with mean dry weight of $49.6,21.6$ and $9.3 \mathrm{mg}^{-1} \mathrm{ind}^{-1}$ for $M$. norvegica, $T$. inermis and $T$. raschi, respectively.

Temperature profiles (Fig. 8) indicate that the depth of the first mode closely corresponded to the temperature minimum in the water column $\left(\sim 0\right.$ to $\left.1^{\circ} \mathrm{C}\right)$, and the second mode to temperatures greater than $2{ }^{\circ} \mathrm{C}$. This is reflected in the frequency distribution of the biomasses of the 2 euphausiid genera against temperature (Fig. 7C, D). Temperature minima in the water column tended to increase from $\sim 0.5^{\circ} \mathrm{C}$ on the north to $\sim 2{ }^{\circ} \mathrm{C}$ on the south (Fig. 8). The temperature profiles showed large variations caused by the horizontal variability, the non-synoptic sampling and temporal variability due to the internal tide (Forrester 1974, Therriault \& Lacroix 1976). Salinity profiles also showed a gradual change from the north to the south (Fig. 8). This reflects the input of salt water from the Gulf of St. Lawrence on the north, and the vertical mixing and flushing of the brackish water of the Upper Estuary and Saguenay by a coastal jet on the south (El Sabh 1979, Therriault \& Levasseur 1985).

The horizontal distribution of temperature and salinity at 0 and $10 \mathrm{~m}$ (Fig. 9) shows the coldest temperatures and highest salinities upstream, at the head of the Laurentian Channel, and along the south coast. Surface salinity and temperature patterns in the downstream section of the sampling area also appeared to have been under the influence of the plume of the Manicouagan and Outardes rivers, located on the north coast about $30 \mathrm{~km}$ downstream of the study area. At 20 and $30 \mathrm{~m}$, the coldest temperatures and highest salinites were found all along the north coast.

\section{DISCUSSION}

\section{Euphausiid biomass estimates}

Biomasses were estimated by mean of the linear regression between the volume scattering strength and the dry weight of the euphausiids caught by net tows (Fig. 2). As pointed out by Pieper (1979), errors in such estimates are mainly due to 2 factors: the variability of the backscattering strength from a given euphausid biomass and the accuracy of the correspondence with net data. Since backscattering from zooplankton is a function of the animal's size (McNaught 1968, Greenlaw 1979, Pieper \& Holliday 1984), a given weight of euphausiids $\mathrm{m}^{-3}$ can have various backscattering 


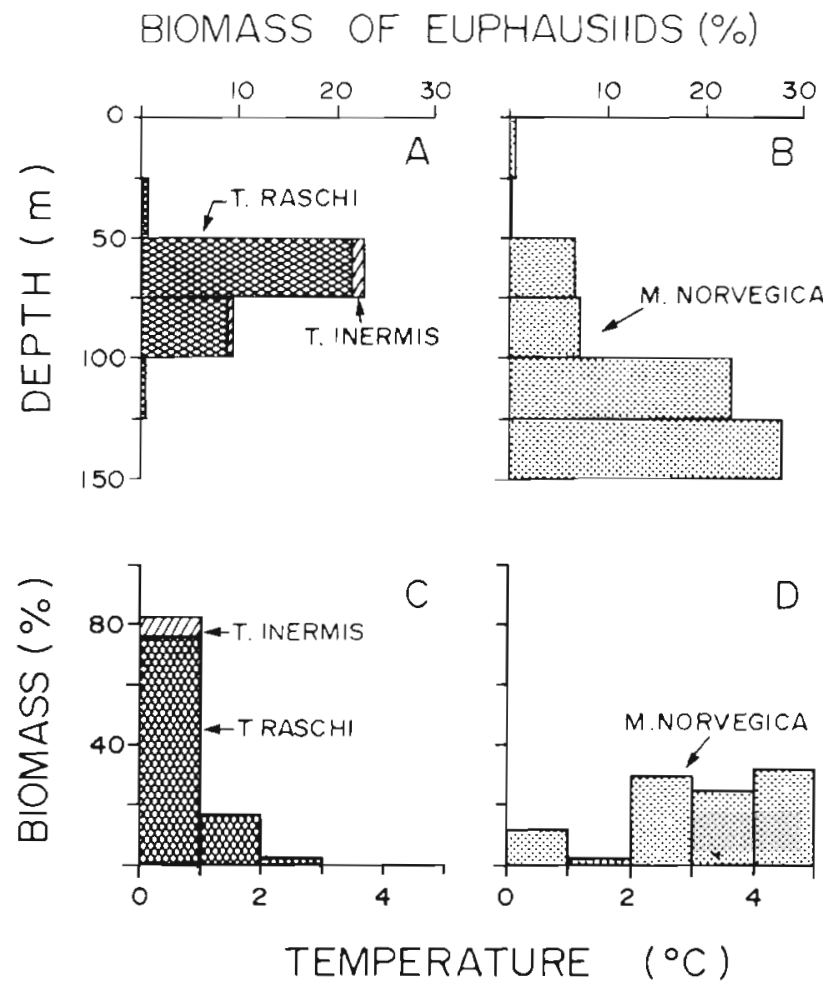

Fig. 7. Distribution of the biomass of euphausiids from net tows. A, B: contribution of (A) Thysanoessa raschi $+T$. inermis and (B) Meganyctiphanes norvegica to the total abundance of euphausiids versus depth. C, D: frequency distribution of the populations of (C) $T$. raschi $+T$ inermis and (D) $M$. norvegica against temperature. Calculated from total catches (dry wt) in each temperature or depth class divided by the corresponding total volume filtered

strengths in response to changes in the distribution of size of the individuals, i.e. the backscattering strength from 10 euphausiids each weighing $10 \mathrm{mg}$ is not necessarily the same as the backscattering from a single euphausiid weighing $100 \mathrm{mg}$. Similarly, since euphausiids are directional scatterers (Greenlaw 1977), a change in volume scattering strength could result merely from a change in the orientation of the euphausiids. This latter problem is minimized by sampling during the day (Sameoto 1980).

Correspondence between acoustic estimates and net catches is never perfect. Though simultaneous and close to one another, the parcels of water sampled by the echosounder and by the net were not exactly the same, because of horizontal spacing, lag, and difference in sample size between the 2 estimates. Since the scattering layers showed strong horizontal and vertical patchiness (e.g. Fig. 5A, B), this lack of exact timespace correspondence could have entailed either too low or too high acoustic estimates compared to the net catches. This was evident in some net tows and can explain a part of the dispersion in Fig. 2. Calibration of echosounding with net sampling should therefore be carried out in areas of low spatial heterogeneity in the scattering layer. Another source of variability is the fishing efficiency of the net, which is dependent on factors such as avoidance by organisms, inadequate net opening and flowmeter malfunctions. We have no evidence of poor net performance. Although the characteristics of this net (large mouth opening, free from bridle obstruction, dark-coloured netting, large mesh size) and the towing speed used would tend to minimize the avoidance problem, we cannot reject the possibility of such a bias. Evidence of avoidance of nets by euphausiids in literature is controversial (Clutter \& Anraku 1968). If it has occurred in our sampling, the bias caused by this source of error would have surely been overriden by the more important bias due to patchiness.

Despite all these important sources of error, the regression between the acoustic estimates and the net catches (Fig. 2) was good, the linear relation explaining $87 \%$ of variance. Echosounding gives therefore estimates of the actual biomass of euphausiids as accurate as those from net sampling, but it has the additional advantage of allowing easy study of the 'grain' of the spatial distribution and, hence, the mechanisms controlling this distribution.
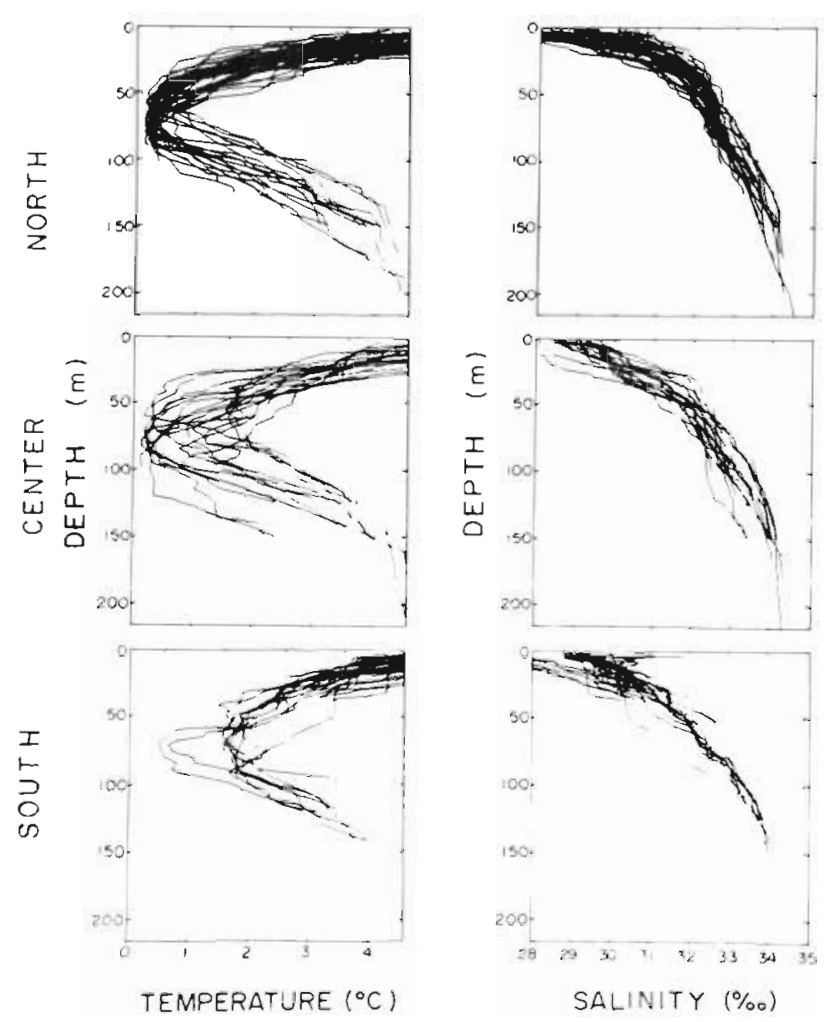

Fig. 8. Cross-channel changes in temperature and salinity profiles in the study area during the survey 
TEMPERATURE $\left({ }^{\circ} \mathrm{C}\right)$
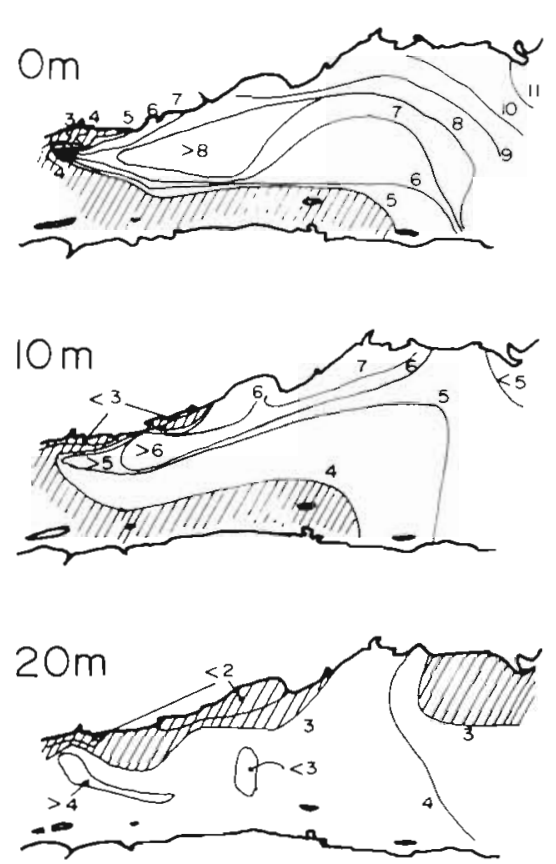

Fig. 9. Horizontal patterns of temperature and salinity at $0,10,20$ and $30 \mathrm{~m}$ in the study area during the survey

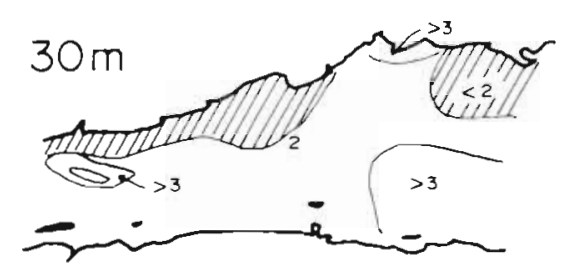

SALINITY (\%o)
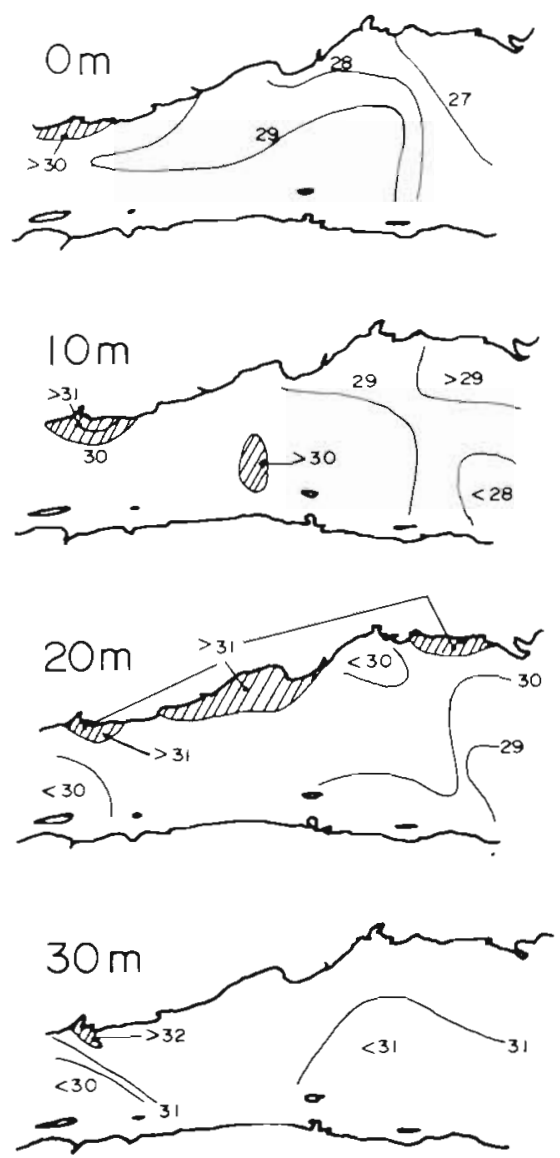

The present results confirm Sameoto's (1976) observation that the sound scattering at $100 \mathrm{kHz}$ in the St. Lawrence estuary is mainly due to euphausiids. Sameoto (1976, 1983) reported biomasses of euphausiids in scattering layers in the estuary and Gulf of St. Lawrence varying between 0.01 and $40 \mathrm{~g}$ wet wt $\mathrm{m}^{-3}$ and between 2.3 and $315 \mathrm{~g}$ wet wt $\mathrm{m}^{-2}$. Given a wet:dry wt ratio of 6 (81 to $87 \%$ water content; Mauchline 1980), the maximum biomasses reported by Sameoto are 2 to 3 times higher than our maximum values ( $15 \mathrm{~g}$ wet $\mathrm{wt} \mathrm{m}^{-3}$ and $133.2 \mathrm{~g}$ wet $\mathrm{wt} \mathrm{m}^{-2}$ ). The mean density found in the scattering layers along the north coast (60 $\mathrm{mg}$ dry wt $\mathrm{m}^{-3}$, Table 2) is similar to those reported for heavy scattering layers in the region in 1972 to 1974 (Sameoto 1976) but it is 1 order of magnitude lower than those observed in May 1976 (Sameoto 1983: 660 to $1180 \mathrm{mg}$ dry wt $\mathrm{m}^{-3}$ ). Densities reported by Pieper $(1979,1983)$ for the scattering layers of California and in a fjord of British Columbia are similar to the present estimates for the St. Lawrence.

\section{Spatial pattern of the aggregation}

Most of the biomass of euphausiids in the study area was concentrated in a long narrow patch $\left(\sim 500 \mathrm{~km}^{2}\right)$ along the northern edge of the Laurentian Channel (Fig. 3). A larger proportion of the water column was inhabited by euphausiids there and the scattering layers were denser than elsewhere in the study area (Tables 1 \& 2).

The differential concentration of particles and organisms at sea depends on the combination of 2 factors: (1) the spatio-temporal structure of the currents, and (2) the properties of the particles (buoyancy, swimming speed and direction, and behavior) (Owen 1981). For the first factor, the circulation pattern in the region favoured a transportation of euphausiids upstream and towards the north. The general mean circulation in the study area is cyclonic, with upstream currents in the northern half and downstream currents in the southern half (Ingram 1975, 1979, El-Sabh 1979). 
At the head of the Laurentian Channel, a large amplitude internal tide (vertical range up to $120 \mathrm{~m}$, Therriault \& Lacroix 1976) is generated (Forrester 1974 ) and causes upwelling of deep water and intensive vertical mixing (Ingram 1975, 1979, 1983, Therriault \& Lacroix 1976). The actual circulation at a given time can also be influenced by important semidiurnal, semi-monthly and other lower frequency fluctuations, and by cross-channel currents (Forrester 1974, El-Sabh 1979, Ingram 1979, El-Sabh et al. 1982). During the sampling period, deep water was upwelled at the head of the Laurentian Channel (Fig. 9; 0 and $10 \mathrm{~m}$ ) and along the north coast (Fig. 9; 10 to $30 \mathrm{~m}$ ). This implies a mean flow in deep waters directed upstream accompanied by a cross-channel flow directed towards the north coast. This deep-water circulation pattern favoured transport of euphausiids upstream and towards the north shore.

In the surface waters, the temperature and salinity patterns (Fig. 9) were consistent with the above cyclonic circulation. The upwelled waters at the head of Laurentian Channel were then directed towards the south shore by the general surface cross-channel flow (Ingram 1979) and mixed with the brackish waters from the Saguenay and the Upper estuary (Ingram 1983, Lebel et al. 1983), before being flushed down along the south shore of the Estuary (El-Sabh 1979, Therriault \& Levasseur 1985). This is supported by the horizontal and vertical distributions of temperature and salinity (Fig. 8, 9). A surface cross-channel flow directed toward the north coast was also probably present in the downstream half of the study area as suggested by the curvatures of the $7^{\circ} \mathrm{C}$ and $29 \%$ isolines (Fig. 9).

Following this general circulation pattern, the euphausiids in deep waters were transported upstream and towards the north coast in the northern half of the area during the day $(16 \mathrm{~h}$ duration, from 0500 to 2100 h). At night, when a significant proportion of the euphausiid population was in the upper water column (see Simard et al. 1986), the euphausiids were also transported upstream along the north coast and downstream along the south shore, with a possible northern cross-channel transport in the downstream section of the study area.

The second factor which may have contributed to the accumulation of euphausiids in a dense patch along the north shore is the avoidance of underwater daylight by the organisms. It is well known that diel vertical migrations of scattering layers in the sea are controlled by underwater light (e.g. Clarke \& Backus 1956, 1964, Boden \& Kampa 1958, 1967, Kampa 1975). According to the model proposed by Forward et al. (1984), animals swim upward in the dark, up to a particular isolume which stimulates a sinking response and, thus, acts as a barrier for vertical displacements. A similar hypothesis had been suggested by Pearre (1973) for chaetognaths. In support of this light-barrier hypothesis are the observations of (1) a close correspondence between the depth of a particular isolume and the top of the scattering layer during diel vertical migrations (Boden \& Kampa 1967), (2) the vertical movements of scattering layers during a total solar eclipse (Kampa 1975), and (3) the observations of the negative phototaxis of the scattering layers in the St. Lawrence in response to the first light of dawn (e.g. Fig. 5C; see also Simard et al. 1985, 1986).

The present observations (Fig. 4, $5 \&$ 6) and those of Simard et al. (1986) in the same area immediately after the present survey suggest that one of the lightlimiting barriers was located at about the 40 to $50 \mathrm{~m}$ depth in the Estuary. The euphausiids would have accumulated upstream and along the north shore below the light barrier, under upwelling conditions. Meganyctiphanes norvegica is known to inhabit greater depths (>100 m) than Thysarioessa raschi (>50 m) (Mauchline 1980), as observed in this study (Fig. $6 \& 7$ ) and thus, the light limitation level might not be the same for the 2 species. Both species swim sufficiently fast $\left(\sim 1\right.$ to $5 \mathrm{~cm} \mathrm{~s}^{-1}$; Hardy \& Bainbridge 1954) to compensate for the vertical mean flow due to upwelling.

In addition to this mechanism, special hydrodynamic conditions associated with the channel slope could also have contributed to the accumulation of euphausiids (closed circulation, internal waves, pulsed intrusions of channel waters on the shelf and their interaction with the euphausiid behavior). Moreover, the association of Thysanoessa raschi with the coldest waters (Fig. 7A, also reported by Sameoto 1976, 1980, Simard et al. 1986) could be a coincidence with an isolume but equally a real temperature preference. With the present data, it is not possible to discriminate between the 2 hypotheses but, if cold waters are actively sought by the organisms, the seasonal upstream advection of the cold intermediate layer from the Gulf of St. Lawrence (Ingram 1979) would also have led to higher concentrations of euphausiids in the Lower Estuary during the summer.

The light-scattering layers observed along the south shore of the channel (Fig. 3, Table 1) could result from the dispersion of the north patch at the head of the Laurentian Channel. Cross-channel currents (Ingram 1979) would drive parts of the patch to the south, where the organisms would be transported downstream by the rapid flushing circulation of the estuary. This turning circulation from the north to the south at the head of the channel is probably marked by important tidal fluctuations. These might cause periodicity in the evacuation pattern of small parts of the north patch, 
which could explain the presence of dispersed small patches of euphausiids on the south (Fig. 3).

In conclusion, the most probable cause of accumulation of euphausiids along isobaths in the St. Lawrence estuary is the interaction between the upwelling and residual circulation and the negative phototaxis behavior of the euphausiids. The organisms are advected upstream and towards the north coast and accumulate along the channel slope in response to their avoidance of underwater light during the day. This patch is slowly dispersed at the head of the Laurentian Channel, where cross-channel currents drive a part of the euphausiids into the flushing jet of the estuary along the south shore. This general pattern is summarized in the schematic model presented in Fig. 10. The degree of persistence of the aggregation as well as the transient or permanent nature of the upwelling is unknown. The June 1973 observations of Sameoto (1976) and our preliminary observations in May 1982 support, however, the fact that the horizontal pattern of euphausiids presented here is at least reproducible, and hence has a certain degree of permanence. Moreover, it has recently been shown from analysis of thermal patterns revealed by satellite photographs (Lavoie et al. 1985), that the upwelling pattern observed here is a common feature of the study area in the St. Lawrence estuary.

Higher concentrations of zooplankton at intermediate distances from the coast have been observed many times (e.g. Hargreaves 1978, Pearcy 1976, Witeck et al. 1981, Leis 1982, Hampton 1983, Rakusa-Suszczewski 1983). Observations with high frequency acoustics (Macaulay et al. 1984, Shulenberger et al. 1984) have recently shown that euphausiid aggregations were closely linked to shelf breaks. Macaulay et al. (1984) suggested that these aggregations resulted from active horizontal migrations of small patches merging, over the shelf break, into a short-living ( 2 to 3 d) large swarm, in response to changes in current velocity as the bottom shoals. Leis (1982) suggested that the coastal distribution of zooplankton along an island resulted from the combination of the diel vertical movement of the organisms with a 2-layer circulation pattern and/or coastal eddies. Our results support that the formation of aggregations of vertically migrating zooplankton around bottom slopes is mainly due to the combination of the circulation at depth with their negative phototaxis.
Fig. 10. A conceptual model of the formation of the euphausiid aggregation in the lower St. Lawrence estuary, under the influence of residual and upwelling circulation and the negative phototaxis of the animals

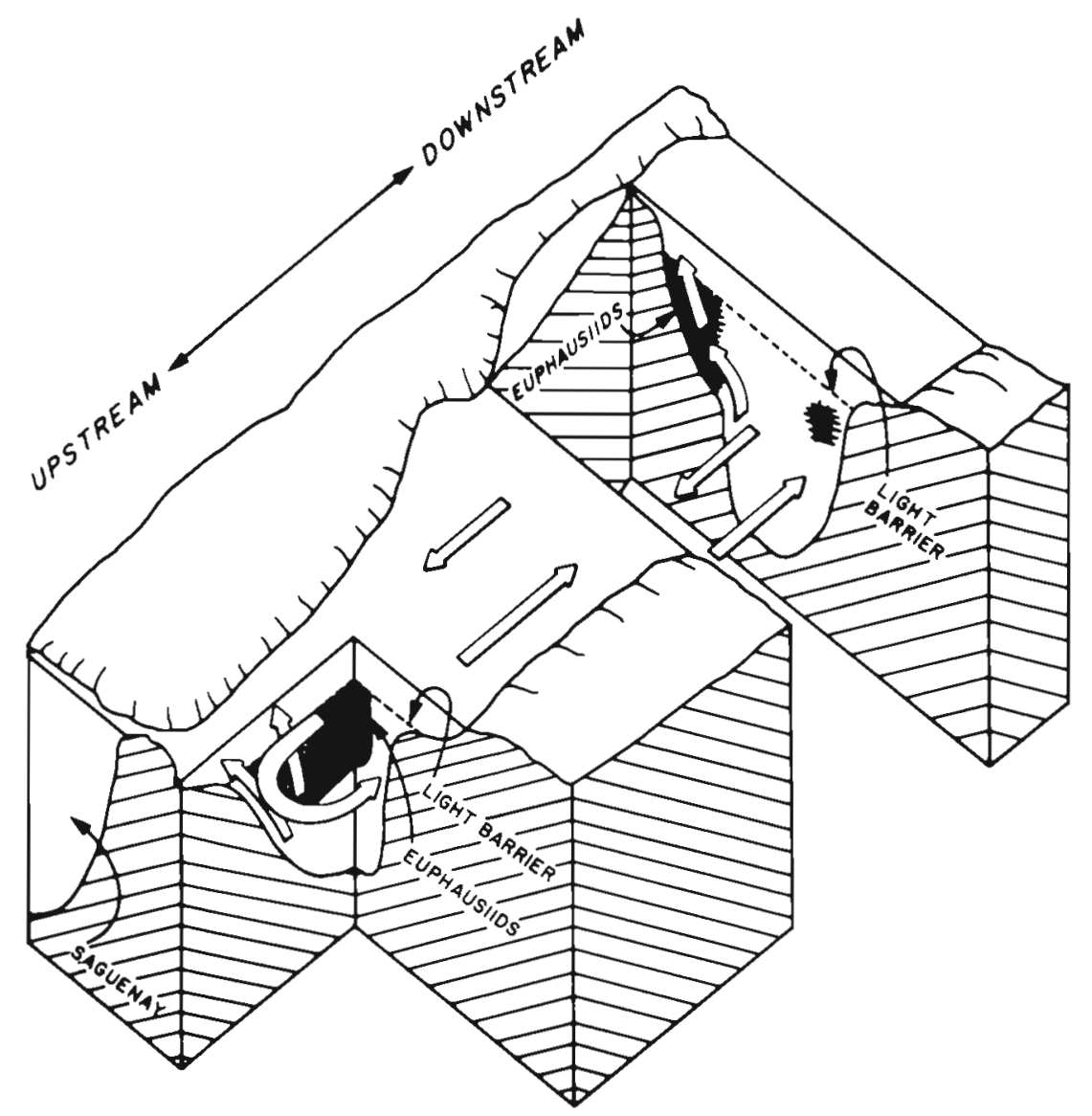


Since euphausiids are an important link in the marine food web these coastal aggregations are of major importance for higher trophic levels. Large concentrations of food are available for coastal pelagic fishes, and benthic fishes can take advantage of the high densities of euphausiids near the bottom during the day (see Isaacs \& Schwartzlose 1965, Pearcy et al. 1979, Omori \& Ohta 1981). This could be an important factor in fish aggregation (see Isaacs \& Schwartzlose 1965, Pereyra et al. 1969) as suggested by our observations of numerous bottom fishes near the channel slope (Fig. 5B). Also, the traditional habit of local fishermen to fish around the $100 \mathrm{~m}$ isobath in the area, and the summer aggregation of fin and blue whales off Les Escoumins are probably not fortuitous and may depend on this coastal aggregation of euphausiids in the St. Lawrence estuary.

Acknowledgements. Sampling was carried out in collaboration with the Groupe Interuniversitaire de Recherche Océanographique du Québec and Laval University to which Y.S. was affiliated at the time. We thank all the research assistants, technicians and colleagues who helped in the work at sea or in the laboratory. The manuscript was completed while Y.S. was attached to the Institute of Ocean Sciences, Department of Fisheries and Oceans, Sidney, British Columbia, which provided support in the final steps of this research.

\section{LITERATURE CITED}

Boden, B. P., Kampa, E. M. (1958). Lumière, bioluminescence et migrations de la couche diffusante profonde en Méditerranée occidentale. Vie et Milieu 9:1-10

Boden, B. P., Kampa, E. M. (1967). The influence of natural light on the vertical migrations of an animal community in the sea. Symp. zool. Soc. Lond. 19: 15-26

Burczynski, J. (1979). Introduction to the use of sonar systems for estimating fish biomass. FAO Fish. Tech. Pap. no. 191, p.1-89

Clarke, G. L., Backus, R. H. (1956). Measurement of light penetration in relation to vertical migration and record of luminescence of deep-sea animals. Deep Sea Res. 4: 1-14

Clarke, G. L., Backus, R. H. (1964). Interrelations between the vertical migration of deep scattering layers, bioluminescence, and changes in daylight in the sea. Bull. Inst. océanogr. Monaco Vol. 64 , no 1318 , p. 1-36

Clutter, R. I., Anraku, M. (1968). Avoidance of samplers. In: Zooplankton sampling. Unesco, Paris, p. 57-76

Denman, K. L., Mackas, D. L. (1978). Collection and analysis of underway data and related physical measurements. In: Steele, J. H. (ed.) Spatial pattern in plankton communities. Plenum Press, New York, p. 85-109

El-Sabh, M. (1979). The lower St. Lawrence Estuary as a physical oceanographic system. Naturaliste can. 106: $55-73$

El-Sabh, M. I., Lie, H.-J., Koutitonsky, V. G. (1982). Variability of the near-surface residual current in the lower St. Lawrence estuary. J. geophys. Res. 87: 9589-9600

Forrester, W. D. (1974). Internal tides in the St. Lawrence estuary. J. mar Res. 32: 55-66
Forward, R. B., Cronin, T W., Stearns, D. E. (1984). Control of diel vertical migration: photoresponse of a larval crustacean. Limnol Oceanogr 29: 146-154

Greenlaw, C. F. (1977). Backscattering spectra of preserved zooplankton. J. acoust. Soc. Am. 62: 44-52

Greenlaw, C. F. (1979). Acoustical estimation of zooplankton populations. Limnol. Oceanogr. 24: 226-242

Hampton, I. (1983). Preliminary report on the Fibex acoustic work to estimate the abundance of Euphausia superba. Proc. of the Biomass Colloquium in 1982. Memoirs of the National Institute of Polar Research, Tokyo, Special issue no 27 : $165-175$

Hardy, A. C., Bainbridge, R. (1954). Experimental observations on the vertical migrations of plankton animals. J. mar. biol. Ass. U.K. 33: 409-448

Hargreaves, P. M. (1978). Relative abundance of zooplankton groups in the northwest African upwelling region during 1968 and 1972. In: Boje, R., Tomczak, M. (ed.) Upwelling ecosystems. Springer-Verlag, New York, p. 62-72

Haury, L. R., McGowan, J. A., Wiebe, P. H. (1978). Patterns and processes in the time-space scales of plankton distributions. In: Steele, J. H. (ed.) Spatial pattern in plankton communities. Plenum Press, New York, p. 277-327

Herman, A. W., Platt, T. (1980). Meso-scale spatial distribution of plankton: Co-evolution of concepts and instrumentation. In: Sears, M., Merriman, D. (ed.) Oceanography: the past. Springer-Verlag, New York, p. 204-225.

Ingram, R. G. (1975). Influence of tidal induced mixing on primary productivity in the St. Lawrence estuary. Mém. Soc. r. Liège 7: 59-74

Ingram, R. G. (1979). Water mass modification in the St. Lawrence Estuary. Naturaliste can. 106: 45-54

Ingram, R. G. (1983). Vertical mixing at the head of the Laurentian Channel. Estuar. coast. Shelf Science 16: 333-338

Isaacs, J. D, Schwartzlose, R. A. (1965). Migrant sound scatterers: interaction with the sea floor. Science 150: 1810-1813

Kampa, E. M. (1975). Observations of a sonic-scattering layer during the total solar eclipse, 30 June, 1973. Deep Sea Res. 22: $417-423$

Lavoie, A., Bonn, F., Dubois, J. M. M., El-Sabh, M. I. (1985). Structure thermique et variabilité du courant de surface de l'estuaire maritime du Saint-Laurent à l'aide d'images du satellite HCMM. Can. J. Remote Sensing 11: 70-84.

Lebel, J., Pelletier, E., Bergeron, M., Belzile, N., Marquis, G. (1983). Le panache du Saguenay. Can. J. Fish. Aquat. Sci. 40: $52-60$

Leis, J. M. (1982). Nearshore distributional gradients of larval fish (15 taxa) and planktonic crustaceans (6 taxa) in Hawaii. Mar. Biol. 72: 89-97

Longhurst, A. R. (1981). Significance of spatial variability. In: Longhurst, A. R. (ed.) Analysis of marine ecosystems. Academic Press, London, p. 415-441

Macaulay, M. C., English, T. S., Mathisen, D. A. (1984). Acoustic characterization of swarms of Antarctic krill (Euphausiia superba) from Elephant Island and Bramfield Strait. J. crustac. Biol. 4: 16-44

Mackas, D. L., Denman, K. L., Abbott, M. R. (1985). Plankton patchiness: biology in the physical vernocular. Bull mar. Sci. 37: 652-674

Mauchline, J. (1980). The biology of mysids and euphausiids. Adv. mar. Biol. 18: 1-681

McNaught, D. C. (1968). Acoustical determination of zooplankton distributions. International association for Great Lakes Research, Ann. Arbor, Michigan, Proc. 11th Conf. Great Lakes Res., p. 76-84

Omori, M., Ohta, S. (1981). The use of underwater camera in 
studies of vertical distribution and swimming behaviour of a sergestes shrimp. Sergia lucens. J. Plankton Res. 3: $107-121$

Ortner, P. B., Pieper, R. E., Mackas, D. L. (1983). Advances in zooplankton sampling. In: Rothschild, B., Rooth, C. (ed.) Report on fish ecology III - A foundation for recruitment experiment. University of Miami Press, p. 355--380

Owen, R. W. (1981) Fronts and eddies in the sea: mechanisms, interactions and biological effects. In: Longhurst, A. R. (ed.) Analysis of marine ecosystems. Academic Press, London, p. 197-233

Pearcy, W. G. (1976). Seasonal and inshore-offshore variations in the standing stocks of micronekton and macrozooplankton off Oregon. Fish. Bull. U.S. 74: 70-80

Pearcy, W. G., Hopkins, C. C. E., Gronvik, S., Evans, R. A. (1979). Feeding habits of cod, capelin and herring in Balsfjorden, northern Norway, July-August 1978: the importance of euphausiids. Sarsia 64: 269-277

Pearre, S. (1973). Vertical migration and feeding in Sagitta elegans Verrill. Ecology 54: 300-314

Pereyra, W. T., Pearcy, W. G., Carvey, F. E. (1969). Sebastodes flavidus, a shelf rockfish feeding on mesopelagic fauna, with consideration of the ecological implications. J. Fish. Res. Bd Can. 26: 2211-2215

Pieper, R. E. (1979). Euphausiid distribution and biomass determined acoustically at $102 \mathrm{kHz}$. Deep Sea Res. 26: $687-702$

Pieper, R. E. (1983). Quantitative estimates of euphausiid biomass determined by high-frequency acoustics. Biol. Oceanogr. 2: 113-149

Pieper, R. E., Holliday, D. V. (1984). Acoustic measurements of zooplankton distributions in the sea. J. Cons. int. Explor. Mer 41: 226-238

Rakusa-Suszczewski, S. (1983). The relationship between the distribution of plankton biomass and plankton communities in the Drake Passage and the Bransfield Strait (Biomass-Fibex, February-March 1981). Proc. of the Biomass Colloquium in 1982. Memoirs of the National Institute of Polar Research, Tokyo, Special issue no 27: 77-83
Sameoto, D. D. (1976). Distribution of sound scattering layers caused by euphausiids and their relationship to chlorophyll a concentrations in the Gulf of St. Lawrence estuary. J. Fish. Res. Bd Can. 33: 681-687

Sameoto, D. D. (1980). Quantitative measurements of euphausids using a $120 \mathrm{kHz}$ sounder and their in situ orientation. Can. J. Fish. Aquat. Sci. 37: 693-702

Sameoto, D. D. (1983). Euphausid distribution in acoustic scattering layers and its significance to surface swarms. J. Plankton Res. 5: 129-143

Sameoto, D. D., Jarozynski, L. O. (1976). Some zooplankton net modifications and development. Can. Tech. Rep. Fish. Res. Bd 679, p. 1-35

Shulenberger, E., Wormuth, J. H., Loeb, V. J. (1984). A large swarm of Euphausia superba: overview of patch structure and composition. J. crustac. Biol. 4: 75-95

Simard, Y., Lacroix, G., Legendre, L. (1985). In situ twilight grazing rhythm during diel vertical migrations of a scattering layer of Calanus finmarchicus. Limnol. Oceanogr. 30: 598-606

Simard, Y., Lacroix, G., Legendre, L. (1986). Diel vertical migrations and nocturnal feeding of a dense coastal krill scattering layer (Thysanoessa raschi and Meganyctiphanes norvegica) in stratified surface waters. Mar. Biol. 91: 93-105

Steele, J. J. (1976). Patchiness. In: Cushing, D. H., Walsh, J. J. (ed.) The ecology of the seas. Blackwell Scientific Publications, London, p. 98-115

Steele, J. H. (1978). Some comments on plankton patches. In: Steele, J. H. (ed.) Spatial pattern in plankton communities. Plenum Press, New York, p. 1-20

Therriault, J.-C., Lacroix, G. (1976). Nutrients, chlorophyll, and internal tides in the St. Lawrence estuary. J. Fish. Res. Bd Can. 33: 2747-2757

Therriault, J.-C., Levasseur, M. (1985). Control of phytoplankton production in the lower St. Lawrence estuary: light and freshwater munoff. Naturaliste can. 112: 77-96

Witek, Z., Kalinowski, J., Grelowski, A., Wolnomiejski, N. (1981). Studies of aggregation of krill (Euphausia superba). Meeresforschung 28: 228-243 